Historic, Archive Document

Do not assume content reflects current scientific knowledge, policies, or practices. 



\section{MAR 151916}

\section{INDEXED: \\ L I R R R $Y$ \\ 1916 \\ RECALTED \\ $\star$ JUL 9 i $1920 \star$

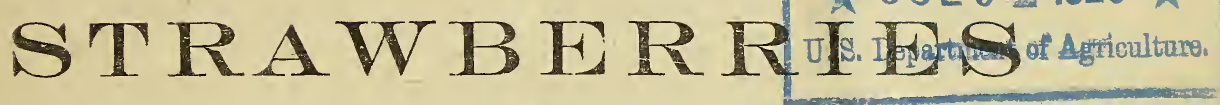 \\ AXD OTHER \\ SMALL FRUITS

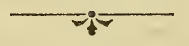 \\ True to Mame}

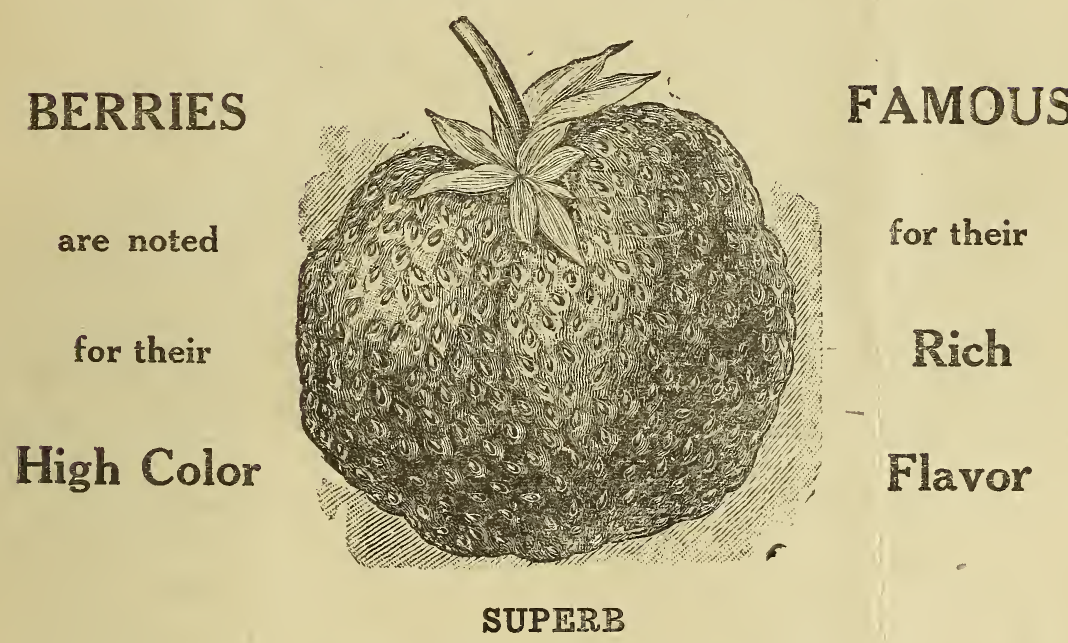

King of all Fverbearers

You may have strawberries from June until November by planting

Superb, Progressive, the best of all everbearing varieties.

Price, 50c per dozen postpaid.

\section{CHAPUT'S NURSERIES \\ R. F. D. No 2 AUBURN, MAINE}




\section{A FEW SUGCESIIONS}

Early orders are our preference. There is nothing to be gained by putting off the order until the last minute. But often disappointment.

The supply of Everbearing Strawberry plants is again very short this season. Notwithstanding, that the acreage was increased ten times that of the past season. The demand is so great that it will be several years before it will be supplied. Take a hint and get your order in now for a few hundred.

For a family garden selection there is nothing better, than a few hundred Superb, grown in hills, every hill will pick a quart, if given proper attention.

Shipping. We advise shipping by express. Our shipping season commences as soon as the frost is out of the ground, and ends Nov. 1st.

True to Name. We endeavor to furnish plants true to name, but will not be responsible for more than the original cost of the stock.

Certificate of Inspection. A certificate of inspection acrompanies each shipment, which insures you that the plants are free from all dangerous plant diseases.

\section{RASPBERRIES-YES}

And the ever bearing large red ones too. We know of no other raspberry as profitable as the St. Regis, especially so for home garden. 25 plants will make you a nice row in your garden and will give a fine lot of fruit for several months each year. We will send 25 plants prepaid for $\$ 1.25$ or 100 plants prepaid for $\$ 3.00$.

\section{BOYS' TRIAL COLLECTION}

I will send 500 plants, best varieties suited for the section from which order is received, to any boy under 18 years of age who will send me $\$ 2.00$ and promise to grow the patch himself, and for the one who sends me the best report, together with photograph of himself and berry patch I will give $\$ 5.00$ in gold.

Get as many boys to send as possible. Mention Boys Club collection when sending in your $\$ 2.00$. Report to be made in July 1917. 


\section{Everbearing Strawberries a Commercial success-Yes}

Plant ever-bearing strawberry plants this spring and you will pick fine delicious berries from June until November. The first years crop will more than pay every cost and a plenty good eats for yourself. One fellow claims $\$ 25.00$ profit from 100 plants set last year. His claim is reasonable for we have had them produce over one quart to each plant set the first season and it is not unusual for them to sell from $25 \mathrm{e}$ to $50 \mathrm{e}$ per quart, in home town.

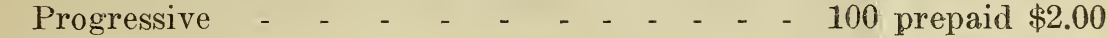
Superb - - - - - - - - - 100 prepaid $\$ 2.00$

Better order now, the stock is short everywhere and if you buy from us you get the everbearing kind.

Senator Dunlap is one of our very best varieties for general purposes. It is easy to grow and a sure cropper everywhere.

Single thousand $\$ 4.00$.

Warfield, is at its best when set alongside of Dunlap, same price.

Some growers prefer setting Warfield and Dunlap in same row, this is an ideal way, every other plant Dunlap.

\section{PRICE LIST OF PLANTS FOR 1916}

These prices take the place of any prices made in former eatalogs, and all sales are made from this date on at prices herein named. All plants at prices given by 100 lots come postpaid, all lots over this amount come express collect. Note in descriptions if variety is Perfect or Imperfect blossom.

Postpaid By Express not paid

Variety

12

100

1000

Abingtoń (P) - - - - - $25 \mathrm{c}$

$75 \mathrm{c}$

Americus (Fall Bearing) - - - 50c

2.00

$\$ 4.00$

Advance (Fall Bearing) - - - 50c

2.00

15.00

Brandywine (P) - - - - - 25c

75

15.00

Bubach (I) - - - - - - 25c

75

4.00

Farly Ozark (P) - - - - - 25c

1.00

5.00

Glen Mary - - - - - - -

Warfield (I) - $\quad-\quad-\quad-\quad-\quad-$

Senator Dunlap(P) - - - - -

Progressive (Fall Bearing) - - -

Superb (Fall Bearing) - - - 50c

75

6.00

75

4.00

75

4.00

2.00

4.00

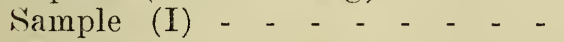

Chesapeake (P) - $\quad-\quad-\quad-\quad-$

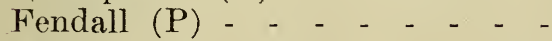

Helen Davis (P) - - - - -

Parsons' Beauty (P) - - - -

Rewastico (P) - - - . - .

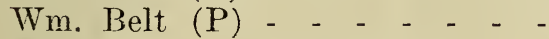

Haverland -

Klondyke - - - - - - - -

Early Jersey Giant - - - _ -

2.00

75

15.00

15.00

75

4.00

75

5.00

75

4.00

75

4.00

75

4.00

75

5.00

75

4.00

75

4.00

75

4.00

4.00

We sell six of a kind at dozen rates; 50 of a kind at 100 rates. 


\section{EVERBEARING VARIETIES}

Superb-S. This is the only fall bearer we consider worth planting and we have tested about every variety as fast as introduced. If you want nice, large, good flavored berries and lots of them in the fall, then plant the Superb in the spring. Keep all blossoms and fruit stem picked as fast as they appear until about July 1. Then you will have all the strawberries you want until frost comes.

Asparagus, 2 year roots. Palmetto; best variety, $\$ 1.00$ per 100 . Horse Radish, Sets 5 cents each, 50 cents a dozen.

St. Regis (Red)-Everbearing, 50c per dozen; $\$ 2.50$ per 100 ; $\$ 15.00$ per 1000 .

\section{RED RASPBERRIES}

Herbert Red Raspberry.-New, large and fine. A Canadian variety and claimed to be as good or better than the Eaton. Price, 50 cents per dozen.

Cuthbert Red Raspberry.-Large, late, hardy and productive. Price, 50 cts per doz.; $\$ 1.25$ per $100 ; \$ 10.00$ per 1000 .

King, Red Raspberry.-(Early King.) Large and fine; productive; one of the best. Price, 50 cts. per doz.; $\$ 1.50$ per 100 .

Plum Farmer-(Black.) The best blackcap raspberry we have ever grown, and the only one we are growing. Earlier than Gregg or Cumberland, equally as large and more productive; the hardiest and best grower: Price, 50 ets per doz.; $\$ 2.00$ per $100 ; \$ 15.00$ per 1000 .

\section{BLACKRERRIFS}

Snyder-Price, Dozen, 35 cts; $50, \$ 1.00 ; 100, \$ 2.00$.

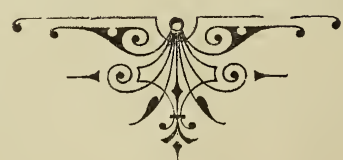

